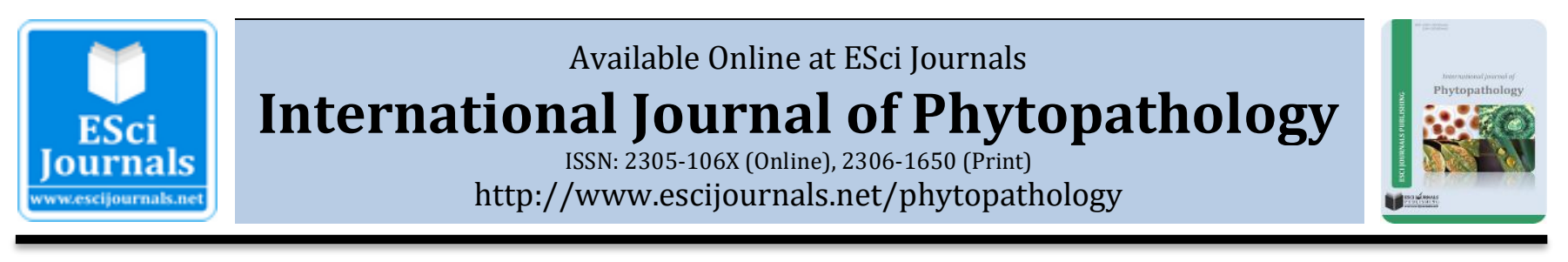

\title{
IMPACT ASSESSMENT OF NEEM COMPOST AND TRICHODERMA HARZIANUM SOLUTION IN THE CONTROL OF ROOT KNOT NEMATODE DISEASE ON COWPEA.
}

\author{
aTimothy I. Olabiyi, bOladiran J. Ojo \\ a Department of Crop and Environmental Protection, Ladoke Akintola University of Technology, Ogbomoso, Nigeria. \\ $\boldsymbol{b}$ International Institute of Tropical Agriculture, P.M.B. 5320, Ibadan Nigeria.
}

\begin{abstract}
A B S T R A C T
Efficacy of neem leaf based compost andTrichoderma harzianum solution were assessed on root knot nematode pest of two cowpea varieties at the screen house of the International Institute of Tropical Agriculture (IITA), Ibadan during 2012 planting season. The two cowpea varieties which have been confirmed to be susceptible to root knot nematode, IT96D-610 and IT84S-2246-4 were the test crops. The experimental pots (10kg soil) were inoculated with 5,000 root knot nematode eggs. The treatments were neem compost and T. harzianum solution with application rates of 2 ton/ha and $1 \times 10^{-7}$ spores respectively. The pots that were not treated served as the control. Each treatment was replicated 4 times while the statistical design was complete randomized design. Data were collected on the growth and yield of cowpea, and also on the nematode populations in the soil and cowpea root. The results indicated that neem compost and T. harzianum solution significantly increased the growth and yield of IT96D-610 and IT84S-2246-4 cowpea varieties grown in the root knot nematode inoculated soil. The populations of root knot nematode in the soil and cowpea root were significantly reduced. The level of root damage (root gall) was significantly reduced in the neem compost and T. harzianum treated cowpea when compared with the untreated control.
\end{abstract}

Keywords: Trichoderma harzianum, root knot nematode, neem compost, cowpea, control.

\section{INTRODUCTION}

Cowpea (Vigna unguiculata (L.) Walp) is an important food legume and essential component of cropping system in the drier region of the tropics and subtropics (Singh et al., 2003), and it is important livelihood of millions of people (Quin, 1997). The grain contains between $20-25 \%$ proteins (Kay, 1979). Cowpea is also a valuable and dependable commodity that produces income for many smallholder farmers and traders in sub-saharan Africa (Langyintuo, 2003). It is a deep rooted crop and does well in sandy soil and more tolerant to drought than soybean (Dadson et al., 2003). It forms a major component of the tropical farming system because of its ability to improve soil fertility through nitrogen fixation (Abayomi et al., 2008). Cowpea can fix about 240 kgha $^{-1}$ atmosphere nitrogen and makes available about 60-70 $\mathrm{kgha}^{-1}$ nitrogen for succeeding crops grown in rotation (Aikins and Afuakwa, 2008).

* Corresponding Author:

Email: tiolabiyi@lautech.edu.ng

(C) 2015 ESci Journals Publishing. All rights reserved.
Plant parasitic nematodes is a serious pest and constitutes a major production constraint to cowpea in most growing areas of the world (Sikora et al., 2005; Sikora and Geco, 1990). Symptoms of nematode on cowpea include stunted growth, yellowing, presence of galls, excessive branching of roots and reduced functioning of root systems. Poor germination and death of seedlings may be observed in case of heavy infestations (Mishra, 1992). Several species of nematode are known to cause losses to cowpea throughout the world. Caveness and Ogunfowora (1985) listed 55 species of plant parasitic nematode associated with cowpea production. The root knot nematode Meloidogyne incognita and $M$. javanica, are documented to cause major losses, with $M$. incognita indicated to be the most detrimental species to cowpea (Sarmah and Sinha, 1995). Sometimes ago, an estimated 59\% cowpea yield loss, caused by $M$. incognita was reported in Nigeria (Ogunfowora, 1976). Olowe (1978) also found $80 \%$ cowpea seedling mortality in a soil with $M$. incognita population density of 1300 second stage 
juveniles (J2). Comprehensive survey of cowpea growing areas in Nigeria revealed root knot nematode present in all the 248 farms; with $M$. incognita, M. javanica and $M$. arenaria present in $52 \%, 44 \%$ and $4 \%$ of the soil samples respectively (Olowe, 2004).

In recent past the concern for the environment, high cost of nematicides, the nonavailability of nematicides in time of need and the hazard they bring as well as the fear of nematodes developing resistance to synthetic nematicides have motivated researchers to exploit alternative way of controlling nematode infection.It is in this regard that nematologistsespecially in the developing world tend to look for indigenous, nonexpensive but effective method of nematode control and with less or no hazard to plant, soil and livestock (Jada, 1993; Umar et al., 2010). Adegbite and Adesiyan (2005) had advocated for the need to develop naturally occurring nematicide which are harmless to man and livestock, but effectivelycontrolled nematodes.

The objective of this research work was therefore to determine the efficacy of neem compost and Trichoderma harzinum solution in the control of root knot nematode on cowpea.

\section{MATERIALS AND METHODS}

The research was conducted in the screen house at the International Institute of Tropical Agriculture (IITA), Ibadan, Oyo State, Nigeria during 2012 cropping season. Sandy loamy soil was collected from a depth of $01-25 \mathrm{~cm}$ from IITA farm, the soil collected was sieved with $2 \mathrm{~mm}$ sieve to avoid plant debris and stones, steam sterilized and filled into plastic bucket of $30 \mathrm{~cm}$ diameter. The inoculum was root-knot nematode egg which was extracted from infected Celosia root in the laboratory using the method described by Hussey and Barker (1973).

The two cowpea varieties which have been confirmed to be susceptible to root knot nematode, IT96D-610 and IT84S-2246-4 were planted. Three (3) seeds were planted per pot and later thinned to one healthy plant per pot. The experimental plastic pots with $10 \mathrm{~kg}$ steam sterilized soil were inoculated with approximately 5000 root knot nematode egg, within the cowpea rhizosphere, using $5 \mathrm{ml}$ syringe at three weeks after planting. The treatments, neem compost and T. harzianum solution, were applied at the rates of 2 ton/ha and $1 \times 10^{-7}$ spores respectively, at four weeks after planting. The pots that were not treated served as the control. Each treatment was replicated 4 times while the statistical design was complete randomized design. Watering,manual weeding and insect control using Cypermethrin 10\% EC were done whenever necessary.

Data were collected on plant height, number of leaves, seed weight, fresh and dry root weights, gall index, initial nematode population and final nematode populations. Gall index was determined using standard rating scheme (Sasser, 1984). At final harvest of the two cowpea varieties, the nematode populations in the root $(10 \mathrm{~g})$ were extracted and counted following the method described by Hussey and Barker (1973), while the nematode population in the soil $(200 \mathrm{ml})$ were assessedusing pie-pan extraction method as described by Whitehead and Hemming (1965). All data collected were subjected to analysis of variance anddifferences between the means were separated using Duncan's multiple range test at $5 \%$ probability level.

\section{RESULTS}

The efficacy of neem compost and Trichoderma harzianum on the growth of two cowpea varieties, IT96D-610 and IT84S-2246-4, planted on root knot nematode infested soil was shown on Table 1 . There was significant difference between the treated pot and untreated pot (control). The cowpea varieties treated with neem compost have higher plant height and number of leaves this was closely followed by those treated by Trichoderma harzianum., IT96D-610 cowpea variety that were treated with Trichoderma harzianum had the highest number of leaves followed by those treated with neem compost while the least plant height and number of leaves per plant were recorded in cowpea that were not treated control.

Table 1. Efficacy of neem compost and T. harzianum on the growth of cowpea varieties planted in root knot nematode infested soil.

\begin{tabular}{lcccc}
\hline Treatment & \multicolumn{2}{c}{ Plant height } & \multicolumn{2}{c}{ Number of leaves } \\
\hline & IT96D-610 & IT84S-2246-4 & IT96D-610 & IT84S-2246-4 \\
\hline Neem compost & $40.3 \mathrm{a}$ & $45.7 \mathrm{a}$ & $50 \mathrm{a}$ & $57 \mathrm{a}$ \\
T. Harzianum & $36.6 \mathrm{a}$ & $38.4 \mathrm{c}$ & $51 \mathrm{a}$ & $53 \mathrm{a}$ \\
Control & $23.4 \mathrm{~b}$ & $24.2 \mathrm{c}$ & $34 \mathrm{~b}$ & $35 \mathrm{~b}$ \\
\hline
\end{tabular}


The efficacy of neem compost and T. harzianum on the yield of cowpea varieties (IT96D-610 and IT84S- 22464) were shown in Table 2. The results obtained from the application of treatments (neem compost and T.harzianum) showed some significant differences from the untreated (control).The plant treated with neem compost have higher number of pod followed by the cowpeaplant,treated with Tharzianum while the lowestnumber of pod per plant were obtained from plants that were not treated (control). Cowpea variety (IT96D-610) that were treated with neem composthad the highest number of seed per pod while cowpea varieties (IT96D-610 and IT84S-2246-4) treated with T.harzianum have the same number of seed per pod. The untreated plant (control) had the lowest number of seed per pod. Cowpea variety (IT84S-2246-4) treated with neem compost had higher weight of seed per pod followed by cowpea variety (IT96D-610) treated with the same treatment,followed by cowpea variety (IT96D-610) treated with T.harzianum, cowpea variety (IT845-2246-4) treated with the same treatment. Lowest in seed weight per pod was obtain in the two cowpea varieties that were not treated (control).

Table 2. Efficacy of neem compost and T. harzianum on the yield of cowpea varieties planted in root knot nematode infested soil.

\begin{tabular}{lcccccc}
\hline & \multicolumn{2}{c}{ Number of pod per plant } & \multicolumn{2}{c}{ Number of seed per plant } & \multicolumn{2}{c}{ Weight of seed per plant } \\
\hline & IT96D-610 & IT84S-2246-4 & IT96D-610 & IT84S-2246-4 & IT96D-610 & IT84S-2246-4 \\
\hline Neem compost & $9 \mathrm{a}$ & $11 \mathrm{a}$ & $8 \mathrm{a}$ & $9 \mathrm{a}$ & $19.1 \mathrm{a}$ & $35 \mathrm{a}$ \\
T. harzianum & 6b & 8b & 8a & 8a & $17.1 \mathrm{a}$ & $13 \mathrm{~b}$ \\
\hline Control & $1 \mathrm{c}$ & 2c & 2b & $2 \mathrm{~b}$ & $3 \mathrm{~b}$ & $3 \mathrm{c}$ \\
\hline
\end{tabular}

The efficacy of neem compost and T. harzianum on the soil root-knot nematode population and root damage on two cowpea varieties (IT96D-610 and IT84S-2246-4) were shown in Table 3. There were significant differences between the treated plant and control on fresh and dry root weight in both varieties (Table3). The control plants havehigher root weight and dry matter weight. The cowpea plants that were treated with neem compost and T. harzianum have lower root weight. There was a higher gall on the cowpea roots in the

\begin{tabular}{|c|c|c|c|c|c|c|c|c|c|c|c|c|c|c|}
\hline \multirow[t]{2}{*}{ Treatment } & \multicolumn{2}{|c|}{$\begin{array}{c}\text { Initial } \\
\text { Population } \\
\end{array}$} & \multicolumn{2}{|c|}{$\begin{array}{c}\text { Fresh } \\
\text { root weight (g) }\end{array}$} & \multicolumn{2}{|c|}{$\begin{array}{l}\text { Dry root weight } \\
(\mathrm{g})\end{array}$} & \multicolumn{2}{|c|}{$\begin{array}{l}\text { Gall } \\
\text { Index }\end{array}$} & \multicolumn{2}{|c|}{$\begin{array}{c}\text { Final nematode } \\
\text { Population } \\
\end{array}$} & \multicolumn{2}{|c|}{ Root extraction } & \multicolumn{2}{|c|}{$\begin{array}{l}\text { Reproduction } \\
\text { factor }\end{array}$} \\
\hline & 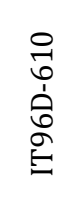 & 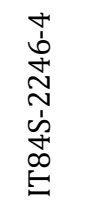 & 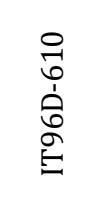 & 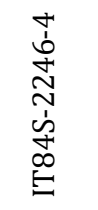 & 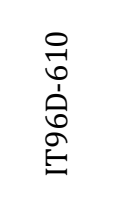 & 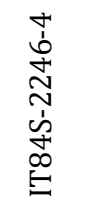 & 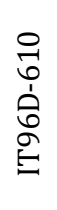 & 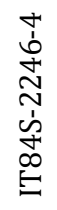 & 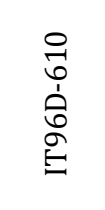 & 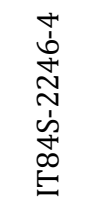 & 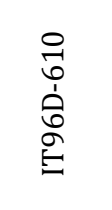 & 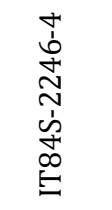 & 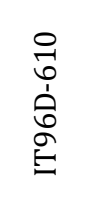 & 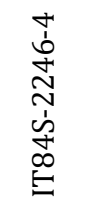 \\
\hline eem & 000 & 5000 & $38 \mathrm{c}$ & $27 \mathrm{~b}$ & b & 0 & 10 & $2 \mathrm{~b}$ & b & 473b & $4 \mathrm{~b}$ & $\mathrm{~b}$ & $0.07 \mathrm{~b}$ & $0.09 \mathrm{~b}$ \\
\hline Harzial & 000 & 5000 & $63 \mathrm{~b}$ & $86 \mathrm{~b}$ & $0.18 \mathrm{~b}$ & $0.10 \mathrm{~b}$ & $1 \mathrm{~b}$ & $1 \mathrm{~b}$ & $428 b$ & $336 \mathrm{~b}$ & $1458 b$ & $1030 \mathrm{~b}$ & $0.09 \mathrm{~b}$ & $0.06 \mathrm{~b}$ \\
\hline Control & 5000 & 5000 & $4.58 \mathrm{a}$ & $3.47 \mathrm{a}$ & $2.41 \mathrm{a}$ & $1.86 \mathrm{a}$ & $5 a$ & $4 a$ & $5876 a$ & $5783 a$ & $8654 a$ & $8558 a$ & $1.75 \mathrm{a}$ & $1.16 \mathrm{a}$ \\
\hline
\end{tabular}

\section{DISCUSSION}

Many fungi and bacterial agents have been examined over a period of time for their potential as bio-control agents (Sharma and Pandey, 2009). Direct pathogenecity of fungi as bio control agents is one of the main mechanisms responsible for plant parasitic nematode control. However, secondary metabolic from fungi also untreated plant (control) ascompared with treated plants. Nematode population in the soil and root were significantly lower in the treated plant. Cowpea variety (IT96D-610) treated with neem compost and cowpea variety (IT24S-2246-4) treated with T.harzianumhave the least population of nematode. The control plants have higher nematode population in both the soil and root. The result of the reproduction factors showed that there was significant decreased in the nematode reproduction potentials in all the treated plants.

Table 3. Efficacy of neem compost and T. harzianum on the soil root knot nematode population and root damage.

contain compounds which are toxic to plant parasitic nematodes (Dabata and Sikora, 2007). Also several attempts have been made to use Trichoderma species to control plant parasitic nematode (Windham et al., 1989). The reproduction of eggs produced by the root knot nematode $M$. incognita following soil treatment with a Trichoderma conida suspension. 
Trichoderma spp have been used as a bio control agent plant parasitic nematode and this fungus may also promote plant and have the ability to colonize root surface and the cortex (Sharon et al., 2001). Trichoderma spp led to inhibition of the nematode activities and movement. Trichoderma vinde in combination with organic amendment was also known to produce growth hormones, which have observed to have added response in boosting the plant vigour. It has been reported that Trichoderma has not only be produced to parasitize nematode and inactive pathogen enzymes but also help in tolerance to stress condition by enhanced root development.Neem compost is a mixture of decaying neem, leaves and it is used in improving the soil quality and fertility also produce essential nutrient to plant and soil. Neem compost has been used by farmers and agriculturist on a large scale because of its benefits.

\section{CONCLUSION}

In conclusion neem compostand Tharzianum (2.0t/ha and $1 \times 10^{-7}$ spores respectively) were effective promising measure for controlling root-knot nematode on cowpea. It is therefore recommended the farmers' use in root knot-nematode endemic areas.

\section{REFERENCES}

Abayomi Y.A., Ajibade T.V., Samuel O.F. and Sa'adudeen B.F. 2008. Growth and yield responses of cowpea (Vigna unguiculata (L.) Walp) genotypes to nitrogen fertilizer (N.P.K.) application in the Southern Guinea Savanna zone of Nigeria. Asian Journal of Plant Sciences. 7(2): 170-176.

Aikins S.H.M. and Afuakwa J.J. 2008. Growth and dry matter yield responses of cowpea to different sowing depths. ARPN Journal of Agricultural and Biological Science. 3(5-6): 50-54.

Caveness, F. E., and Ogunfowora, A. O. 1985. Nematological studies worldwide. Pp. 273-285 in S. R. Singh and K. O. Rachie, eds. Cowpea Research, Production and Utilisation. Chichester, UK: John Wiley and Sons.

Dababat, A.F.A.A. and R.A. Sikora, 2007. Use of Trichoderma harzianum and Trichoderma viride for the biological control of Meloidogyne incognita on Tomato. Jordan J. Agric. Sci., 3: 297-308.

Dadson R.B., Hashem F.M., Javaid I, Joshi J. and Allen A.L. 2003. Response of diverse cowpea genotypes to drought. (CD-ROM) Annual meeting abstracts. ASA, CSSA, SSSA, Madison, WI.
Kay D.E. 1979. Food legumes, crop and product digest, No.3. Natural Resources Institute, Chattan, UK. p. 214.

Langyintuo A.S., Lowenberg-DeBoer J., M. Faye et al., 2003. Cowpea supply and demand in West and Central Africa. Field Crops Research. 82(2-3): 215231

Luc, M., Sikora, R.A. and Bridge, J. (Eds). Plant parasitic nematodes in subtropical and tropical agriculture, 2nd edition, Wallingford, UK, CABI.Publishing, pp. 259-318.

Mishra S.D., 1992: Nematode pests of pulse crops In: Nematodes pests of Vegetable crops, D. S. Bhatti and R.K.Walia, eds. CBS Publishers and Distributors, Delhi India. 140pp.

Ogunfowora, A. O. 1976. Research on Meloidogyne at the Institute of Agricultural Research and Training, University of Ife,Moor Plantation, Ibadan. Pp. 9-14 in Proceedings of the Research and Planning Conference on Root-Knot Nematodes, Meloidogyne spp., June 7-11, 1976, Ibadan, Nigeria: International Institute of Tropical Agriculture.

Olowe, T. 1978. International Meloidogyne project. Proceedings of the Second Research Planning Conference on Root-Knot Nematodes, Meloidogyne spp. February 20-24, Abidjan, Ivory Coast.

Olowe, T. 2004. Occurrence and distribution of root-knot nematodes, Meloidogyne spp., in cowpea growing areas of Nigeria. Nematology 6:811-817.

Quin F.M., 1997: Importance of cowpea. Pp. Ix-xii In: Advances in cowpea research. B.B.

Sarmah, B., and Sinha, A. K. 1995. Pathogenicity of Meloidogyne incognita on Cowpea. Plant Health 1:1-12.

Sasser, J.N. (1984). An Advance Treatise on Meloidogyne, Biology and Control, North Carolina StateUniversity, Graphics. 1st Edition, PP 15-25.

Sharma, P. and R. Pandey, 2009. Biological control of root-knot nematode, Meloidogyne Incognita in the medicinal plant, Withania somnifera and the effect of biocontrol agents on plant growth. Afr. J. Agric. Res., 4: 564-567.

Sharon, E., M. Bar-Eyal, I. Chet, A. Herrera-Estrella, O. Kleifeld and Y. Spiegel, 2001. Biological control of root knot nematode Meloidogyne javanica by 
Trichoderma harzianum. Phytopathology, 91: 687-693.

Sikora R.A., N. Greco, 1990: Nematode parasites of food legumes. Pp. 197-198 In: Plant parasitic nematodes in Subtropical and Tropical Agriculture. M. Luc, R. A. Sikora and J. Bridge, eds. 1st edition, Wallingford, UK, CABI Publishing.

Sikora R.A., N. Greco, J, F.V. Silva, 2005: Nematode parasites of food legumes. In:

Singh B.B., J.D. Ehlers, B. Sharma, F.R. Freirefilho, 2003: Recent progress in cowpea breeding. Pp. 22-40 In Challenges and opportunities for enhancing sustainable cowpea production. Proceedings of the World Cowpea Conference III held at IITA Ibadan, Nigeria. 4-8 September, 2002.

Singh, K.E. Dashiell, D. R. Mohan Raj and L.E.N. Jackai, eds. Colorcraft, Hong Kong, China.

Whitehead, A.G and J.R. Hemming (1965). A comparison of some quantitative methods of extracting small veniform nematodes from soil. Annl. Appl.Bio. 55: 25-38.

Windham, G.L., M.T. Windham and P.W. Williams, 1989. Effects of Trichoderma spp. on maize growth and Meloidogyne arenaria reproduction. J. Plant Dis.,73: 493-495. 